\title{
Barriers to Climate Change Adaptation Among Pastoralists: Rwenzori Region, Western Uganda
}

\author{
Michael Robert Nkuba, Raban Chanda, Gagoitseope Mmopelwa, \\ Akintayo Adedoyin, Margaret Najjingo Mangheni, David Lesolle, \\ and Edward Kato
}

\section{Contents}

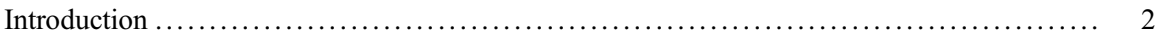

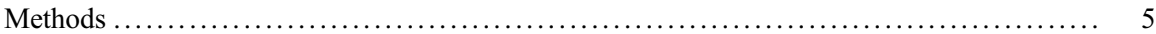

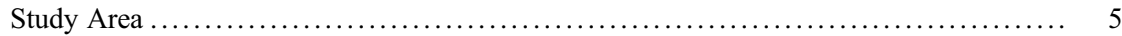

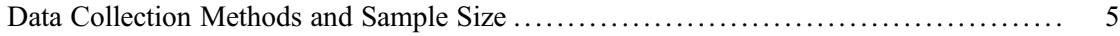

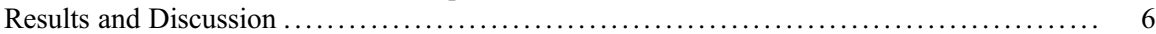

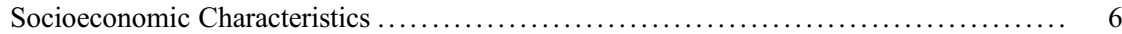

Barriers to Climate Change Adaptation among Pastoralists ..................... 8

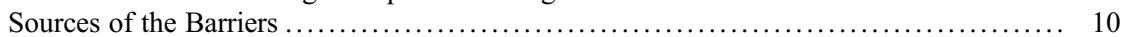

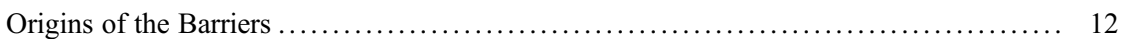

Enablers of Adaptation in Uganda .......................................... 14

This chapter was previously published non-open access with exclusive rights reserved by the Publisher. It has been changed retrospectively to open access under a CC BY 4.0 license and the copyright holder is "The Author(s)". For further details, please see the license information at the end of the chapter.

M. R. Nkuba $(\bowtie) \cdot$ R. Chanda $\cdot$ G. Mmopelwa $\cdot$ D. Lesolle

Department of Environmental sciences, Faculty of Science University of Botswana, Gaborone, Botswana

e-mail:mnkuba@gmail.com; chandar@mopipi.ub.bw; gmmopelwa@mopipi.ub.bw; david. lesolle@mopipi.ub.bw
A. Adedoyin
Department of Physics, Faculty of Science, University of Botswana, Gaborone, Botswana e-mail: akintayo_adedoyin@yahoo.com

\section{N. Mangheni}

Department of Extension and Innovation Studies, College of Agricultural and Environmental Sciences, Makerere University Kampala, Kampala, Uganda

e-mail: mnmangheni@gmail.com

\section{E. Kato}

International Food Policy and Research Institute, Washington, DC, USA

e-mail: E.Kato@cgiar.org 


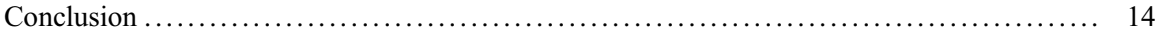

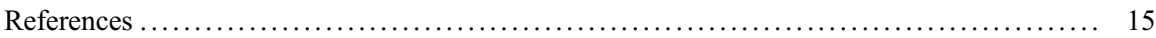

\section{Abstract}

This chapter discusses the barriers to climate change adaptation among pastoralists in the Rwenzori region in Western Uganda. Despite the implementation of adaptation programs by public and private agencies, pastoralists still have impediments to adapting to climate change. Data was collected using a household survey involving 269 pastoralists. The results revealed that the main barriers were poor access to climate change information, poor access to extension services, high cost of adaptation measures, poor access to credit, and insecure land tenure. There is need to improve capacity building of extension workers and other stakeholders in the dissemination of climate change information. Land tenure and land rights issues should be given high consideration in climate change adaptation policies and programs. Climate finance programs should be made more effective in addressing the high cost of adaptation.

\section{Keywords}

Barriers $\cdot$ Adaptation $\cdot$ Climate change $\cdot$ Pastoralists $\cdot$ Rwenzori $\cdot$ Uganda

\section{Introduction}

Climate change is one of the greatest threats to achieving the sustainable development goals related to eradicating poverty and hunger and ensuring clean water and life on land in Africa (IPCC 2018c). Despite the increased efforts at both national and international levels in the form of climate finance and programs, pastoralists still have barriers to adapting to climate change. Failure to adapt to climate change has resulted into high livestock mortality leading to a poor quality of life among pastoral households (IPCC 2014b). The impacts of global warming of $1.5{ }^{\circ} \mathrm{C}$ above preindustrial levels are likely to lead to an increase in droughts and floods in Africa, especially in pastoral areas (IPCC 2018a). This could result in a failure to achieve sustainable development goals (IPCC 2018c). Pastoralists have adapted to climate change with various strategies that include livestock diversification, destocking, livestock migration, and engagement in nonfarm enterprises (Greenough 2018; IPCC 2014b). However, some pastoral households have been more vulnerable than others to climate change, resulting in loss of livestock (Greenough 2018). This implies that there are hindrances to adaptation.

Developing countries such as those in Africa still have challenges in addressing the hindrances, leading to an adaptation deficit when compared to developed countries in Europe (IPCC 2014a; Shackleton et al. 2015). These hindrances are categorized as limits and barriers. Barriers refer to impediments that can be easily overcome, while limits refer to impediments that cannot be easily overcome (IPCC 2014a). Many scholars have written about the barriers to adaptation without scrutinizing their causes (Filho and Nalau 2018; Shackleton et al. 2015). Moser and 
Ekstrom (2010) argue that barriers have various causes which have to be addressed for successful adaptation to be achieved. The issues of concern include the context of the pastoral household, type of pastoral household, and the governance system of the natural resource. This suggests that smallholder pastoralists experience different barriers compared to large-scale pastoralists. Rangeland policies that promote sedentary pastoralism have different barriers compared to those that promote mobile pastoralism (Löf 2013; Shackleton et al. 2015). These policies have strong implications for the governance system and context of pastoralism. For example, sedentary policies in pastoralism have a detrimental effect on the land tenure system that does not promote herd mobility as a coping mechanism for droughts (Little et al. 2008). This then becomes a barrier.

The barriers that have been identified include economic, biophysical, financial, informational, sociocultural, governmental, and institutional (Alam et al. 2018; Antwi-Agyei et al. 2015; IPCC 2014a; Shackleton et al. 2015). Juana et al. (2016) reported that barriers identified among livestock farmers in Botswana included poor access to improved technology; lack of land, extension workers, credit, and markets; and government restrictions on land use. Muller and Shackleton (2014) showed that the main barriers to commercial livestock farmers in semiarid East Cape in South Africa were poor access to finance, lack information on climate change adaptation and climate information, and lack of government support. This shows that there are barriers that are unique to livestock farmers and pastoralists.

The "barrier to adaptations" diagnostic framework was used to analyze the causes of the barriers (Moser and Ekstrom 2010). This was in order to have a robust investigation of the causes of the barriers, leading to measures of overcoming them. The analysis took into account the sources of the barriers that include the pastoralists (actors), context (governance and economic setting), and socio-ecological system in the rangelands (system of concern) (Moser and Ekstrom 2010). The larger context refers to the level of socioeconomic development and the control of information flow at national and local government level associated with climate change adaptation. Governance refers to the laws, policies, implementation frameworks, and resource allocation at national and local government levels that are associated with the socio-ecological system. The socio-ecological system refers to rangelands, herdsmen, and pastoral households. The socio-ecological system produces signals of environmental change (Moser and Ekstrom 2010) in terms of floods and droughts, although droughts have slow onset and may not be easily detected by the pastoralists. Early warning systems such as seasonal climate forecasts that are disseminated via mass media are not usually observed (Luseno et al. 2003). Pastoralists tend to use indigenous forecasts in their adaptation to extreme weather events despite their reliability and accuracy being affected by climate change (Speranza et al. 2010). Some pastoralists use both indigenous and scientific forecasts (Lybbert et al. 2007). The analysis also took into consideration the temporal dimension of the barrier sources, which include recent occurrence (contemporary issue) or occurrence 
over a long time (legacy issue) (Moser and Ekstrom 2012). The purpose was to find out when the barriers came into play. The spatial jurisdiction origin of the barrier in relation to pastoralists includes proximate, referring to the origin of the barrier being within pastoralists' cycle of influence, and remote, referring to the origin of the barrier being outside the pastoralists' cycle of influence, for example, government policies (Moser and Ekstrom 2010). The idea was to examine which barriers were within the cycle of influence of the pastoralists.

This chapter examines the barriers to adaptation among pastoralists in the Rwenzori region in Western Uganda. The key question is what are barriers to adaptation among pastoralists? The sources and origins of the barriers are examined to provide strategies for overcoming them. The objective is to generate empirical evidence that could be used by policymakers, development partners, extension workers, and nongovernmental organizations to address the barriers among pastoralists to improve their adaptation to climate related risks. The chapter contributes to pastoral literature that relates to barriers to climate change adaptation in Africa. The scope of this chapter addresses barriers among pastoralists in the tropical equatorial region in Western Uganda and does not cover arable farmers and pastoralists in semiarid areas.



Fig. 1 Location map of study area. (Source: Michael Robert Nkuba) 


\section{Methods}

\section{Study Area}

The study on barriers to adaptation among pastoralists was conducted in Kasese and Ntoroko districts found in the Rwenzori region in Western Uganda (Fig. 1). There are a few weather stations used to provide the climate data of the region. The rangelands in the study area are conducive to pastoralism and wildlife conservation, and wildlife protected areas (WPAs) exist in the area. WPAs include Queen Elisabeth National Park in Kasese district and Tooro-Semiliki Game Reserve in Ntoroko district (Fig. 1). As an adaptation strategy for climate change, pastoralists migrate to the eastern part of the Democratic Republic of Congo. Political instability in Eastern DR Congo tends to cause large numbers of pastoralists to migrate back to Uganda (KRC and RFPJ 2012). However, some pastoralists illegally graze in WPAs. The Uganda Wildlife Authority imposes heavy penalties on pastoralists who illegally graze in WPAs. The emphasis on sedentary pastoralism in government rangeland policies has led to a reduction in mobile pastoralism in Uganda (Wurzinger et al. 2006, 2009). The region has a bimodal rainfall distribution and experiences droughts and floods with increased frequency (NAPA 2007).

\section{Data Collection Methods and Sample Size}

Data collection took place from August to October 2015 in the Rwenzori region. Household surveys gathered data on barriers to adaptations, socioeconomic characteristics, and use of indigenous forecasts (IFs) and/or scientific forecasts (SFs). A two-stage stratified sampling design was used (Cochran 1963), in which the strata were the districts and the second stage units were households. Stratified sampling was based on farming systems and agro-ecosystems in the Rwenzori region. Random sampling was used to select the respondents for the survey. The sample size was 778 households, with a $95 \%$ confidence level and a margin of error of $3.5 \%$, based on the total population of the study area (the Rwenzori region and the Kibale district) of 102,496 households, according to Uganda population census report 2014. However, to allow for replacement in the sample of those who might back out of the study, and have good sizes for subsamples for those who use IF and SF and IF only, $19 \%$ of the statistically selected sample was included, giving a total study sample of 924. This was also to ensure a good sample size for subsamples (for those who use IF and SF and IF only). After data cleaning, 17 questionnaires were excluded from the analysis due to incomplete responses. Of the remaining 907 respondents, 580 were arable farmers, 269 pastoralists, and 57 agro-pastoralists. For this chapter, the sample size is 269 from pastoral areas in Kasese and Ntoroko districts. Data was analyzed using Stata 12. The scope of this chapter addresses barriers among pastoralists in the tropical equatorial region in Western Uganda and does not cover arable farmers and pastoralists in semiarid areas. 


\section{Results and Discussion}

\section{Socioeconomic Characteristics}

The descriptive characteristics show that respondents were mostly male (59\%) (Table 1) with an average number of local cows produced in the previous last 12 months being 70 per pastoral household. Pastoralists mainly used both IFs and SFs $(59 \%)$ or IFs only $(41 \%)$ in their adaptation to climate-related risks (Table 2). The use of indigenous forecasts has enhanced climate change adaptation and disaster management in Africa and South America (IPCC 2018b). Climate-related risks experienced were floods and droughts. The majority $(47 \%)$ had attained primary education, and $38 \%$ had no formal education. The common adaptation methods were livestock migration, herd mobility, livestock diversification and livestock sales. Enablers to adaptation included access to land through purchasing (suggesting that

Table 1 Socioeconomic characteristics of respondents

\begin{tabular}{|c|c|c|}
\hline Variable & Variable definition & $\begin{array}{l}\text { Full sample } \\
(N=269)\end{array}$ \\
\hline Female & Gender of the respondent ( 1 if female) & 0.41 \\
\hline Male & Gender of the respondent ( 1 if male) & 0.59 \\
\hline No school & $\begin{array}{l}\text { Respondent had no formal school education (1 if } \\
\text { yes) }\end{array}$ & $0.38(0.50)$ \\
\hline Primary & Respondent attained primary education ( 1 if yes) & $0.47(0.50)$ \\
\hline Secondary education & $\begin{array}{l}\text { Respondent attained ordinary or advanced } \\
\text { secondary education ( } 1 \text { if yes) }\end{array}$ & $0.12(0.33)$ \\
\hline Farm experience & $\begin{array}{l}\text { Farming experience of the respondent in completed } \\
\text { years }\end{array}$ & $27.72(13.84)$ \\
\hline Age & Age of the respondent in completed years & $44.26(13.25)$ \\
\hline Kasese & Respondent resides in Kasese district ( 1 if yes) & $0.17(0.38)$ \\
\hline Ntoroko & Respondent resides in Ntoroko district ( 1 if yes) & $0.81(0.40)$ \\
\hline Drought experience & Respondent has had drought experience ( 1 if yes) & $0.96(0.20)$ \\
\hline Flood experience & Respondent has had flood experience ( 1 if yes) & $0.82(0.39)$ \\
\hline Herd mobility & Respondent practices herd mobility ( 1 if yes) & $0.55(0.50)$ \\
\hline $\begin{array}{l}\text { Livestock } \\
\text { diversification }\end{array}$ & $\begin{array}{l}\text { Respondent practices livestock diversification (1 if } \\
\text { yes) }\end{array}$ & $0.54(0.50)$ \\
\hline Livestock migration & Respondent practices livestock migration ( 1 if yes) & $0.83(0.38)$ \\
\hline Selling livestock & Respondent practices selling livestock ( 1 if yes) & $0.51(0.50)$ \\
\hline Well construction & Respondent practices well construction ( 1 if yes) & $0.31(0.46)$ \\
\hline Nonfarm & $\begin{array}{l}\text { Respondent engages in nonfarm enterprises (1 if } \\
\text { yes) }\end{array}$ & $0.08(0.27)$ \\
\hline Owns boats & Owns boats ( 1 if yes) & $00.11\left(\begin{array}{lll}0 & 0.32\end{array}\right)$ \\
\hline Owns fishnet & Owns fishnet (1 if yes) & $0.10\left(\begin{array}{lll}0 & 0.30\end{array}\right)$ \\
\hline $\begin{array}{l}\text { Local cattle produced } \\
\text { last } 1 \text { year }\end{array}$ & $\begin{array}{l}\text { Local cattle produced in the last } 12 \text { months } \\
\text { (numbers) }\end{array}$ & $69.97(58.56)$ \\
\hline
\end{tabular}

Source: Field data 2015 Figures in parentheses are standard deviations 


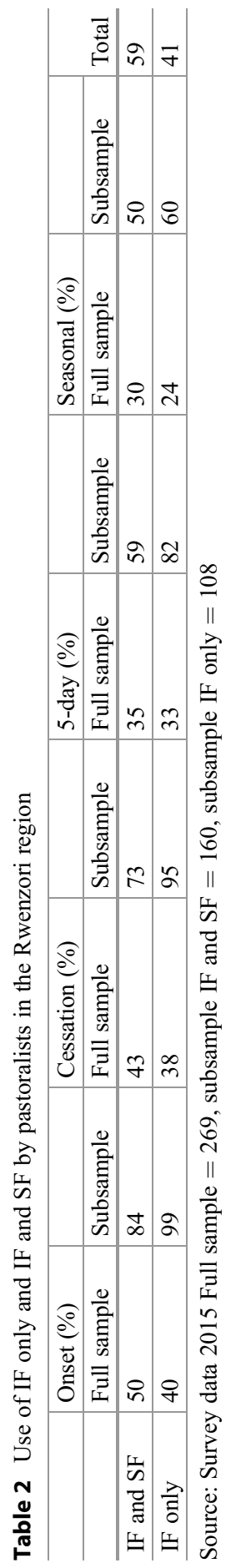


Table 3 Pastoralists' land tenure and access to land

\begin{tabular}{l|l|l}
\hline Variable & Variable definition & $\begin{array}{l}\text { Full sample } \\
(N=269)\end{array}$ \\
\hline Customary & Customary $(1$ if yes) & $0.34(0.47)$ \\
\hline Freehold & Freehold $(1$ if yes) & $0.14(0.35)$ \\
\hline Inheritance & Inheritance $(1$ if yes) & $0.40(0.49)$ \\
\hline Purchased & Purchased $(1$ if yes) & $0.33(0.47)$ \\
\hline Grabbed & Grabbed 1 if yes $)$ & $0.05(0.22)$ \\
\hline
\end{tabular}

Source: Survey data 2015 Figures in parentheses are standard deviations

Table 4 Barriers to climate change adaptation among pastoralists

\begin{tabular}{l|l|l}
\hline & Mean & Std. Dev. \\
\hline Inadequate or no access to extension services & 0.27 & 0.44 \\
\hline Inadequate or no information on climate change & 0.49 & 0.50 \\
\hline Lack of access to credit facilities & 0.18 & 0.38 \\
\hline Insecure land tenure or property rights & 0.09 & 0.29 \\
\hline High cost of hired labor & 0.15 & 0.36 \\
\hline High cost of adaptation measures & 0.26 & 0.44 \\
\hline Labor shortages & 0.08 & 0.27 \\
\hline No barrier & 0.04 & 0.20 \\
\hline
\end{tabular}

Source: Field Data 2015

functional land markets existed) and inheritance (Table 3). Pastoralists diversified their livelihoods to include other natural resources such as fisheries resources, which were demonstrated by ownership of boats and fishnets (Table 1).

\section{Barriers to Climate Change Adaptation among Pastoralists}

The high cost of adaptation is a major barrier in wealthy pastoral households (Table 4). According to a key informant, it costs $\$ 800$ to construct a private dam, and sinking a borehole would cost $\$ 5400$ in the study area. These costs are high for smallholder pastoralists. The key informant also said that the government program, National Agricultural Advisory Services (NAADS), used to provide fence materials to a few model pastoralists. The NAADS program ended in 2014, and the cost of infrastructure development in pastoral areas is high. The fencing materials were provided to a few pasture demonstration farmers (Dalipagic and Elepu 2014; GoU 2018). The government also provided tractors for pasture improvement but not water for pastoralists (NAADS 2017). Climate finance should address such barriers. The Uganda government provided support for the construction of over 650 communal valley dams and 135 private dams for ranches in the rangelands (Nema 2001). Some of these dams dried up during droughts resulting in livestock mortality and an increase in herd mobility (Zziwa et al. 2012). Lack of hydrographic surveys for 
communal valley dams, poor designing of water sources without taking into account the rangeland dynamics and context, poor maintenance, and lack of community ownership were the main factors that led to the poor performance of communal valley dams (Mugerwa et al. 2014; Nema 2001). Community involvement in the management of micro-dams is higher in the Southwest and Central regions of Uganda $(40-50 \%)$ than in the North and Northwest regions, where it is very low (less than 10\%) (Bashar et al. 2004).

The poor performance of valley dams has increased water scarcity in the rangelands, resulting in an increase of mobile pastoralism and sociopolitical conflicts (Nema 2007), yet the government built the water sources to promote sedentary pastoralism. Even in situations where there was good performance and management of the dams, there was land degradation of the rangelands surrounding the water source (Egeru et al. 2015). Individual pastoralists tend to manage their private water sources better than they manage communal ones. The Botswana government provides support to livestock farmers with infrastructural development assistance, such as for fencing materials, and construction of boreholes to improve their adaptive capacity against droughts (Pauw 2013). Climate finance should support pastoral initiatives toward adaptation by providing fencing materials and sustainable water sources in communal rangelands and paddocks (Denton 2010).

Poor access to climate change information and poor access to extension services were also important barriers to adaptation among pastoral households. Extension workers have not mainstreamed climate change information in their dissemination of extension messages, but emphasis has been put on livestock production (AfranaaKwapong and Nkonya 2015; GoU 2016; Nkonya et al. 2015). Furthermore, in Uganda (as elsewhere in Africa) the extension system has gone through many changes from a unified extension system (1981-2000) to a demand-driven extension under the NAADS (2001-2014), to the current single-spine extension system (2015 to date) (Barungi et al. 2016; GoU 2016; Rwamigisa et al. 2018). The extension services have been tailored to sedentary but not mobile pastoralism. The demand-driven extension system under NAADS was relevant not to mobile pastoralists but to sedentary pastoralists. The extension did not serve all the pastoralists but concentrated on a few, especially model farmers (AfranaaKwapong and Nkonya 2015; GoU 2016). Furthermore, pastoralists in remote areas did not access extension services (AfranaaKwapong and Nkonya 2015). There were also a limited number of qualified service providers in rural areas, resulting in services engaging unskilled and poor quality providers (Feder et al. 2011; GoU 2016). Most of the service providers had such a narrow scope of the subject matter that they were incompetent and lacked capacity to handle other aspects such as plant and animal diseases (GoU 2016; Rwamigisa et al. 2018). There was reportedly much political interference with the implementation of demand-driven extension service (Joughin and Kjær 2010; Rwamigisa et al. 2018). This included the use of members of the Uganda Peoples Defence Forces in the distribution of inputs and various presidential directives on the implementation of the extension services, especially during election periods (Rwamigisa et al. 2018).

Poor access to credit facilities as a barrier mostly applied to small-scale sedentary pastoralists. Large-scale pastoralists tended to finance their livestock enterprises through destocking, using rural livestock markets (Bryan et al. 2013). Furthermore, 
these pastoralists diversified into fishing and other nonfarm enterprises (Nkuba and Sinha 2014). The large-scale pastoralists were much more involved in livestock migration to the DR Congo as a means of adapting to climate-related risk. During severe droughts, large-scale pastoralists incur losses but recover much more quickly than small-scale pastoralists (Little et al. 2001). According to key informants, about 10,000 cattle were lost in the Ntoroko district during the severe drought of 2011. In some cases, smallholders tend to resort to agro-pastoralism in a sedentary life after high livestock mortality due to severe drought (Berhanu and Beyene 2015).

Insecure land tenure or property rights (Table 4) was another barrier to climate change adaptation in pastoralism. The rangeland policy in Uganda supports sedentary pastoralism (Byakagaba et al. 2018), while pastoralists with land enjoy dual grazing rights. During the rainy season, they graze their livestock in the paddocks. However, during pasture and water scarcity periods, such as during long dry spells and droughts, they graze communally. The areas that used to be grazed communally have been taken up by crop farmers and wealthy pastoralists who have paddocks. Over the years, "the commons" have therefore shrunk in the Rwenzori region, yet the cattle population has not decreased substantially (GoU 2006). During political instability in the DR Congo, the livestock population in rangelands of Ntotoko is much higher than its carrying capacity. The debate concerning having titled land in rangelands and communal grazing land in the cattle corridor continues. Dual grazing rights of wealthy livestock farmers who have access to large acreages have also been reported in Botswana as a coping mechanism during severe droughts (Perkins 1996).

Labor shortages and the associated high cost of labor for pastoralism (Table 4) have been caused by the labor dynamics in the study region. Most herdsmen are youth, many of whom have resorted to nonfarm activities such as motorcycle hire services (commonly called bodaboda) in rural areas. Furthermore, there has been a mass migration of the youth from pastoral households to urban centers and towns in search of so-called greener pastures. Thus, the high demand for herdsmen in the face of a diminished labor supply in rangelands has led to the high cost of labor. The labor of herdsmen is in high demand for such adaptation strategies as livestock migration to the DR Congo, herd mobility to River Semiliki, and pasture lands in the neighborhood of the protected areas.

\section{Sources of the Barriers}

The question that remains is whether pastoralists can overcome these barriers. As noted earlier, to answer this question, the sources of barriers needed to be identified using the barriers to adaptations diagnostic framework. The sources were then analyzed using the three structural elements in the framework, namely, the actors (referring to pastoralists), governance (referring to policies, implementation frameworks, and laws that govern adaptation or hinder it), and socio-ecological system (life in the rangeland, sometimes referred to as system of concern) (Moser and Ekstrom 2010). The three structural elements were used to examine strategies of overcoming the barriers, as is reflected in the following discussion. 
The high cost of adaptation was due to the poor performance of valley dams, an insufficient number of water sources in the rangelands, policy emphasis on support for communal water sources at the expense of individual pastoralists, and equity concerns where support was only given to a few model pastoralists. This suggests that the sources of barriers were principally governance (institutional), technological, and human resource concerns. As a solution, pastoralists could be supported in infrastructure development such as fencing and construction of dams (in communal rangelands) and of boreholes in paddocks for sedentary pastoralists using climate finance from both national and international agencies. The recent change in extension policy from demand-driven extension to single-spine may also help mainstream climate change in its implementation and take into account cost of adaptation (GoU 2016). This implies an increase in allocation of resources related to climate change adaptation. The poor performance of valley dams had a bearing on the hydrological dynamics in rangelands, implying that the socio-ecological system was also a source of barrier. This can be overcome by making good use of the available expertise in hydrology to carry out feasibility studies before the water sources are constructed. Human resources in hydrology and appropriate technology for the various agroecological zones from the Ministry of Water and Environment should be utilized to good effect, both in monitoring and in program design of water for agricultural production facilities (GoU 1999).

The source of barriers such as poor access to climate change information and poor access to extension services was governance (institutional concerns). From a governance perspective, rangeland and extension policies were not relevant to the context. Past extension policies, both the unified extension policy, which used the training and visit system, and the demand-driven policy under NAADS, did not meet the expected outcomes (Rwamigisa et al. 2018; World Bank 2007). This has been mitigated through the new extension policy based on the single-spine extension system, which also has mainstreamed climate change information in the extension messages (GoU 2016). However, the new rangeland policy is not compatible with the socio-ecological system (Byakagaba et al. 2018). Mobile pastoralism makes good use of fragile ecosystems in the rangelands under changing climate conditions (Bailey and Brown 2011; Weber and Horst 2011). Instead, the ultimate goal of the new policy is to convert hitherto mobile pastoralists into agro-pastoralists and sedentary farmers (Wurzinger et al. 2009). There is therefore need to lobby the policy-makers to take into account both mobile and sedentary pastoralism in the rangeland policy. There is also the problem of inadequate human resources in terms of extension officers to serve the entire country. Only $35 \%$ of the technical positions in local governments had been filled in 2016 (GoU 2016). This can be overcome through increased supply and recruitment of qualified labor from tertiary agricultural institutions in the country, such as Makerere University and Bukalasa Agricultural College. Provision of incentives to extension staff is also critical to achieving sustainable outcomes.

Poor access to credit facilities is an actor-centric barrier. This can be overcome with pastoralists joining savings and credit organizations dedicated to pastoralists (Mpiira et al. 2014), probably supported by climate finance arrangements. 
Insecure land tenure or property rights are governance-related barriers arising from concern related to the contradictory rangelands and land-use policies. The land policy promotes mobile pastoralism (GoU 2013) while land-use and rangeland policies discourage mobile pastoralism (GoU 2006); hence there is lack of policy coherence. This is another reason to lobby for change in the land-use and rangeland policies to take into account mobile pastoralism concerns.

The high cost of labor and labor shortages are governance-related and actorcentric barriers. From the governance perspective, there is a need for government policies that attract youth in rural areas of rangelands. The Ugandan government has passed a minimum wage law, but it is unclear how effective it will be in rangelands. From the actor perspective, pastoralists need to increase the amount of wages paid to herdsmen to attract more youth in the socio-ecological system.

\section{Origins of the Barriers}

The origins of the barriers were investigated using temporal and spatial analysis (Table 5).

Lack of credit is a contemporary and proximate barrier, implying that it is within the cycle of influence of pastoralists and a more recent barrier that can be overcome. Wealthy pastoralists finance their enterprises from destocking using rural livestock markets. Destocking is also a climate change adaptation strategy. Thus, poor access to credit mostly applies to the poor sedentary pastoralists. There has been prevalence of savings and credit organizations (SACOs) in rural areas even among pastoralists (Mpiira et al. 2014).

The high cost of hired labor is a contemporary and legacy barrier, implying it is within the cycle of influence of pastoralists and has been in play over a long time. The rural-urban migration of youth in the socio-ecological system has led to an increase in the cost of labor. The youth nowadays prefer to engage in nonfarm activities such as the motorcycle hire business (popularly known locally as bodaboda), and move to urban centers. The promotion and implementation of universal primary education (UPE) even in pastoral areas has improved the skills of youth and provided opportunities outside the rangelands (Appleton 2001). Before the implementation of UPE, the cost of labor was very low as the supply of labor was high because many youth did not go to school. This barrier can be overcome by

Table 5 Opportunities for influence and intervention to overcome the barriers

\begin{tabular}{l|l|l|l}
\hline & \multicolumn{3}{|c}{ Temporal } \\
\hline \multirow{2}{*}{$\begin{array}{l}\text { Spatial } \\
\text { Jurisdictional }\end{array}$} & Contemporary & Legacy \\
\cline { 2 - 4 } & Proximate & Lack of access to credit & High cost of hired labor \\
\cline { 2 - 4 } & Remote & $\begin{array}{l}\text { Insecure land tenure, high } \\
\text { cost of adaptation }\end{array}$ & $\begin{array}{l}\text { Inadequate or no access to } \\
\text { extension services } \\
\text { Inadequate or no information on } \\
\text { climate, labor shortages }\end{array}$ \\
\hline
\end{tabular}

Source survey data 2015. Adapted from Moser and Ekstrom (2010) 
encouraging pastoralists to destock and by enabling them to obtain credit to finance their labor needs.

Insecure land tenure or property rights and the high cost of adaptation are contemporary and remote barriers, implying that they are a recent occurrence but outside the cycle of influence among the pastoralists due to change in government policies. Mobile pastoralism was commonly practiced in the cattle corridor in Uganda. The increase in human and livestock populations and conflicts among pastoralists and with pastoralists in the neighboring arable farming communities resulted in a change of government support, from mobile pastoralism to sedentary pastoralism. The change in rangeland land policy from mobile pastoralism to sedentary pastoralism is a result of armed conflict between arable farmers (from Teso) and pastoralists (the Karamanjong) in northeastern parts of Uganda. Before 1980, mobile pastoralism thrived in Uganda, until the Karamanjong got access to arms, which led to armed conflict in the rangelands (USAID 2011). The change in the land policy and act, with an emphasis on titling land, resulted in the shrinking of the commons in the rangelands, in turn resulting in an increase in insecure land tenure among the commoners (GoU 2013). This barrier could be mitigated through amending the land policy to provide for common grazing lands in land policy in the rangelands and to avoid titling every piece of land in Uganda. This debate has been ongoing among the various nonstate actors since the enactment of the land act in 2004 (Byakagaba et al. 2018). Blanket policy recommendations did not take into account the local setting in different parts of the cattle corridor.

The high cost of adaptation can be overcome through an increase in climate finance to include support to more pastoralists who are not model farmers, as is the current practice under the NAADS implementation framework. There has been a change in the national extension policy from the demand-driven to the single-spine NAADS, which is more inclusive and has taken into account equity concerns (GoU 2016).

Poor access to extension services and climate change information and labor shortages are legacy and remote barriers, implying that they lie outside the cycle of influence of pastoralists and have been in existence over a long period of time. Extension services should have provided the climate change information to the pastoralists, but the ineffective demand-driven extension policy had detrimental outcomes on both. This has fortunately been mitigated through the change in extension policy from the demand-driven to single-spine model (GoU 2016). The new policy promotes mainstreaming climate change information and providing services to all pastoralists.

Labor shortages are due to the failure of a minimum wage law and effective rural development strategies to address the rural-urban migration in Uganda. As observed earlier, educated youth will no longer work for very low incomes as herdsmen in pastoral areas. Recently government passed a minimum wage law whose outcomes are yet to be evaluated in rangelands. It is hoped that this will serve to retain youth in rangelands and promote urban-rural migration among the youth that have already left for urban areas. There is need for government to implement effective rural development strategies that would make rural areas more attractive to the youth. 
So far, strategies such as the Plan for Modernisation of Agriculture have not been effective in reversing the rural-urban migration of the youth.

It is noteworthy that the remote barriers are due to national policies such as extension and land policies that were heavily influenced by donors such the World Bank (Deininger 2003; Deinlnger and Binswanger 1999; Rwamigisa et al. 2018). Local ownership, support to home-grown initiatives, and bottom-up approaches to climate change adaptation would enhance and facilitate the development of the adaptive capacity of pastoralists against these barriers (World Bank 2007) .

\section{Enablers of Adaptation in Uganda}

Alongside barriers to climate change adaptation, studies have also identified adaptation enablers (Azhoni et al. 2018), such as human resource, institutional, governance, and economic enablers (Moser and Ekstrom 2012). In Uganda, climate change adaptation enablers include the following:

- Human resources, such as extension staff and climate change adaptation researchers, pastoralists with indigenous knowledge of climate change adaptation and forecasts.

- Institutions, such as climate change units and climate change policy, research centers for agricultural innovations, the Uganda National Meteorological Authority that provides early warning information and seasonal climate forecasts, mass media that disseminates climate and climate change information (GoU 2015).

- Economic, such as national and local government resource allocations to climate change adaptation initiatives, donor support from Denmark, the United States, Ireland, the United Kingdom, Belgium, Norway, the World Bank, the United Nations Development Programme, support for climate-smart agriculture from the Food and Agricultural Organisation of the United Nations, nonstate actors such as nongovernment organizations implementing climate change adaptation initiatives at local government level such as Oxfam, World Vision, Care, Volunteer Effort for Development Concerns (GoU 2015).

- Political will both at national and local government levels and parliamentary fora on climate change. The government provides mechanisms for flexible and negotiated cross-border access to pastoral resources under the land policy, such as access to rangelands in Eastern DR Congo (GoU 2013).

\section{Conclusion}

The study has established that the barriers to pastoralism are mainly actor-centric and governance concerns. The main barriers were poor access to climate change information, poor access to extension services, high cost of adaptation measures, poor access to credit, and insecure land tenure. Some of the policies under which pastoralism is practiced hinder adaptation to climate change. A change in the policies 
will enhance adaptation; for example, the recent change from the unified extension system and demand-driven extension system to the single-spine system will help in overcoming poor access to extension services and climate change information. Climate finance programs should be made more effective in addressing the high cost of adaptation. Enhancing social capital can help in overcoming poor access to credit. A change in land-use and rangeland policies will help in mitigating insecure land tenure. Coherence of land, land-use, extension, and rangeland policies will enhance pastoral adaptive capacity. It is noteworthy that there are several enablers for climate change adaptation in Uganda, which could be exploited to good effect.

The key lessons learned are that policies associated with climate change adaptation either hinder or enhance the adaptive capacity of pastoral households. Enhancing social capital such as pastoralists' savings and credit groups facilitates access to credit, which improves the capacity to overcome some barriers. Climate finance should be administered in an equitable manner to improve the adaptive capacity for both wealthy and poor households in rural areas.

Future prospects for overcoming barriers in developing countries lie in the identification of the origins and sources of the barriers for effective policy interventions. Policy coherence in climate change adaptation implementation is critical to achieving sustainable development goals, especially Goals 13 and 15, which address the problems of climate change and terrestrial ecosystems, respectively. Mainstreaming climate change in, and effective implementation of, rural development policies will improve the ability of pastoralists to overcome the barriers to climate change adaptation. Rangeland policies should promote both mobile and sedentary pastoralism.

Acknowledgments The authors are grateful for the support during the research from research assistants and the respondents who made this research a reality through their favorable cooperation. This research was self-financed by the lead author for data collection, and special thanks to Nassali Mercy Nkuba for moral support. We are grateful to Kabarole Research and Resource Centre for their collaboration during the field work and the Government of Uganda for permission to carry out the study. Special thanks to Susane Moser and Julia Ekstrom for the insights in the diagnostic framework. This research is part of $\mathrm{PhD}$ work for Michael Robert Nkuba, who wishes to thank the University of Botswana for waiving tuition costs.

\section{References}

AfranaaKwapong N, Nkonya E (2015) Agricultural extension reforms and development in Uganda. J Agric Extd Ural Dev 7(4):122-134

Alam GM, Alam K, Mushtaq S, Khatun MN, Leal Filho W (2018) Strategies and barriers to adaptation of hazard-prone rural households in Bangladesh Limits to Climate Change Adaptation. Springer, Swirtezland, (pp. 11-24)

Antwi-Agyei P, Dougill AJ, Stringer LC (2015) Barriers to climate change adaptation: evidence from Northeast Ghana in the context of a systematic literature review. Clim Dev 7(4):297-309

Appleton S (2001) What can we expect from universal primary education? In: Uganda's recovery: the role of farms, firms, and government. The World Bank, Washington, DC, pp 371-406

Azhoni A, Jude S, Holman I (2018) Adapting to climate change by water management organisations: enablers and barriers. J Hydrol 559:736-748 
Bailey DW, Brown JR (2011) Rotational grazing systems and livestock grazing behavior in shrubdominated semi-arid and arid rangelands. Rangel Ecol Manage 64(1):1-9

Barungi M, Guloba M, Adong A (2016) Uganda's Agricultural Extension Systems: How appropriate is the Single Spine Structure? Research report No 15. Economic Policy Research Centre. Makerere University-Kampala

Bashar K, Kizaa M, Chane B, Seleshi Y (2004) Assessment of existing micro dams in Ethiopia, Sudan and Uganda. Micro-dam Group Nile Basin Capacity Building Network River Engineering. River Structure Research Cluster. Adis Ababa

Berhanu W, Beyene F (2015) Climate variability and household adaptation strategies in Southern Ethiopia. Sustainability 7(6):6353-6375

Bryan E, Ringler C, Okoba B, Roncoli C, Silvestri S, Herrero M (2013) Adapting agriculture to climate change in Kenya: household strategies and determinants. J Environ Manage 114:26-35. https://doi.org/10.1016/j.jenvman.2012.10.036

Byakagaba P, Egeru A, Barasa B, Briske DD (2018) Uganda's rangeland policy: intentions, consequences and opportunities. Pastoralism 8(1):7

Cochran WG (1963) Sampling Technique. (Vol. 2nd Edition,). New York.: John Wiley and Sons Inc

Dalipagic I, Elepu G (2014) Agricultural value chain analysis in northern Uganda: Maize, rice, groundnuts, sunflower and sesame. Against Hunger (ACF) International. Kampala, Uganda

Deininger KW (2003) Land policies for growth and poverty reduction. World Bank Publications, Washington DC

Deinlnger K, Binswanger H (1999) The evolution of the World Bank's land policy: principles, experience, and future challenges. World Bank Res Obs 14(2):247-276

Denton F (2010) Financing adaptation in least developed countries in West Africa: is finance the 'real deal'? Clim Pol 10(6):655-671

Egeru A, Wasonga O, MacOpiyo L, Mburu J, Tabuti JR, Majaliwa MG (2015) Piospheric influence on forage species composition and abundance in semi-arid Karamoja sub-region, Uganda. Pastoralism 5(1):12

Feder G, Birner R, Anderson JR (2011) The private sector's role in agricultural extension systems: potential and limitations. J Agribus Dev Emerg Econ 1(1):31-54

Filho WL, Nalau J (2018) Introduction: limits to adaptation. Springer, Cham

Government of Uganda (GoU) (1999) National water Policy. Ministry of Water and Environment. Kampala, Uganda

Government of Uganda (GoU) (2006) The Uganda National landuse Policy. Ministry of Land Housing and Urban Devlopment Kampala, Uganda

Government of Uganda (GoU) (2013) The Uganda National land Policy. Ministry of Land Housing and Urban Devlopment Kampala, Uganda

Government of Uganda (GoU) (2015) National climate change Policy. Ministry of Water and Environment. Kampala, Uganda

Government of Uganda (GoU) (2016) National Agricultural Extension Policy. Ministry of Agriculture, Animal industry and Fisheries. Entebbe, Uganda

Government of Uganda (GoU) (2018) Guidelines For Use Of Production And Marketing Grant By Local Governments For Fy 2018/19. Ministry of Agriculture, Animal industry and Fisheries. Entebbe, Uganda

Greenough KM (2018) Pastoralists shifting strategies and perceptions of risk: post-crisis recovery in Damergou, Niger. In: Limits to climate change adaptation. Springer, Switerzland, pp 129-142

IPCC (2014a) Climate change 2014: adaptation opportunities, constraints, and limits. Retrieved from Cambridge University Press, Cambridge, UK/New York

IPCC (2014b) Climate change 2014: impacts, adaptation, and vulnerability. Part B: regional aspects. Retrieved from Cambridge University Press, Cambridge, UK/New York

IPCC (2018a) Impacts of $1.5^{\circ} \mathrm{C}$ of Global Warming on Natural and Human Systems. Retrieved from Cambridge University Press, Cambridge, UK/New York

IPCC (2018b) Strengthening and implementing the global response. Retrieved from Cambridge University Press, Cambridge, UK/New York 
IPCC (2018c) Sustainable development, poverty eradication and reducing inequalities. Retrieved from Cambridge University Press, Cambridge, UK/New York

Joughin J, Kjær AM (2010) The politics of agricultural policy reform: the case of Uganda. Forum Dev Stud 37(1):61-78

Juana JS, Okurut FN, Makepe PM, Kahaka Z (2016) Climate change perceptions and adaptations for livestock farmers in Botswana. Int J Econ Issues 9(1):1-21

KRC \& RFPJ (2012) Stuck in the Mist: Contextual Analysis of the Conflicts in the Rwenzori Region. KRC (Kabarole Research and Resource Centre) and RFPJ (Rwenzori Forum for Peace and Justice). Fort Portal, Uganda

Little PD, Smith K, Cellarius BA, Coppock DL, Barrett C (2001) Avoiding disaster: diversification and risk management among East African herders. Dev Chang 32(3):401-433

Little PD, McPeak J, Barrett CB, Kristjanson P (2008) Challenging orthodoxies: understanding poverty in pastoral areas of East Africa. Dev Change 39(4):587-611

Löf A (2013) Examining limits and barriers to climate change adaptation in an Indigenous reindeer herding community. Clim Dev 5(4):328-339

Luseno WK, Mcpeak JG, Barrett CB, Little PD, Gebru G (2003) Assessing the value of climate forecast information for pastoralists: evidence from Southern Ethiopia and Northern Kenya. World Dev 31(9):1477-1494. https://doi.org/10.1016/S0305-750X(03)00113-X

Lybbert TJ, Barrett CB, Mcpeak JG, Luseno WK (2007) Bayesian herders: updating of rainfall beliefs in response to external forecasts. World Dev 35(3):480-497. https://doi.org/10.1016/j. worlddev.2006.04.004

Moser SC, Ekstrom JA (2010) A framework to diagnose barriers to climate change adaptation. Proc Natl Acad Sci 107(51):22,026-22,031

Moser SC, Ekstrom JA (2012) Identifying and overcoming barriers to climate change adaptation in San Francisco Bay. California Energy Commission. Sacramento, CA 95814, USA

Mpiira S, Kiiza B, Katungi E, Tabuti J, Staver C, Tushemereirwe W (2014) Determinants of net savings deposits held in savings and credit cooperatives (SACCOs) in Uganda. J Econ Int Financ 6(4):69-79

Mugerwa S, Kayiwa S, Egeru A (2014) Status of livestock water sources in Karamoja sub-region, Uganda. Resour Environ 4(1):58-66

Muller C, Shackleton SE (2014) Perceptions of climate change and barriers to adaptation amongst commonage and commercial livestock farmers in the semi-arid Eastern Cape Karoo. Afr J Range Forage Sci 31(1):1-12

NAADS (2017) NAADS Strategic Plan 2015/16 - 2019/20. Ministry of Agriculture, Animal industry and Fisheries. Entebbe, Uganda

NAPA (2007) Uganda National Adaptation Plans of Action. Ministry of Water and Environment. Kampala, Uganda

NEMA (2001) State of the Environment Report for Uganda 2001. National Environment Management Authority (NEMA), Kampala. Uganda

NEMA (2007) State of the Environment Report for Uganda 2007. National Environment Management Authority (NEMA), Kampala, Uganda

Nkonya E, Place F, Kato E, Mwanjololo M (2015) Climate risk management through sustainable land management in Sub-Saharan Africa. In Sustainable Intensification to Advance Food Security and Enhance Climate Resilience in Africa. Springer, Switzerland, (pp. 75-111)

Nkuba MR, Sinha N (2014) Aquaculture and fishers' livelihood diversification in Uganda -an empirical analysis. Paper presented at the IASTED international conference environment and water resource management (AfricaEWRM 2014), Gaborone

Pauw P (2013) The role of perception in subsistence farmer adaptation in Africa: enriching the climate finance debate. Int J Clim Change Strategies Manage 5(3):267-284

Perkins J (1996) Botswana: fencing out the equity issue. Cattleposts and cattle ranching in the Kalahari Desert. J Arid Environ 33(4):503-517 
Rwamigisa PB, Birner R, Mangheni MN, Semana A (2018) How to promote institutional reforms in the agricultural sector? A case study of Uganda's National Agricultural Advisory Services (NAADS). Dev Policy Rev 36(5):607-627

Shackleton S, Ziervogel G, Sallu S, Gill T, Tschakert P (2015) Why is socially-just climate change adaptation in sub-Saharan Africa so challenging? A review of barriers identified from empirical cases. Wiley Interdiscip Rev Clim Change 6(3):321-344

Speranza CI, Kiteme B, Ambenje P, UrsWiesmann, Makali S (2010) Indigenous knowledge related to climate variability and change: insights from droughts in semi-arid areas of former Makueni District, Kenya. Clim Change 100:295-315. https://doi.org/10.1007/s10584-009-9713-0

USAID (2011) Climate Change and Conflict in Uganda: The Cattle Corridor and Karamoja. CMM Discussion Paper No 3 USAID. Kampala, Uganda

Weber KT, Horst S (2011) Desertification and livestock grazing: the roles of sedentarization, mobility and rest. Pastoral Res Policy Pract 1(1):19

World Bank (2007) World Development report 2008. Agriculture for Development. World Bank. Washington DC, USA

Wurzinger M, Ndumu D, Baumung R, Drucker A, Okeyo A, Semambo D et al (2006) Comparison of production systems and selection criteria of Ankole cattle by breeders in Burundi, Rwanda, Tanzania and Uganda. Tropl Anim Health Prod 38(7):571-581

Wurzinger M, Okeyo AM, Semambo D, Souml J (2009) The sedentarisation process of the Bahima in Uganda: an emic view. Afr J Agric Res 4(11):1154-1158

Zziwa E, Kironchi G, Gachene C, Mugerwa S, Mpairwe D (2012) The dynamics of land use and land cover change in Nakasongola district. J Biodivers Environ Sci 2(5):61-73

Open Access This chapter is licensed under the terms of the Creative Commons Attribution 4.0 International License (http://creativecommons.org/licenses/by/4.0/), which permits use, sharing, adaptation, distribution and reproduction in any medium or format, as long as you give appropriate credit to the original author(s) and the source, provide a link to the Creative Commons license and indicate if changes were made.

The images or other third party material in this chapter are included in the chapter's Creative Commons license, unless indicated otherwise in a credit line to the material. If material is not included in the chapter's Creative Commons license and your intended use is not permitted by statutory regulation or exceeds the permitted use, you will need to obtain permission directly from the copyright holder.

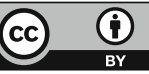

